Relations industrielles

Industrial Relations

\title{
Errol Black and Jim Silver, eds. Hard Bargains. The Manitoba Labour Movement Confronts the 1990's
}

\section{Terry Hercus}

Volume 47, numéro 3, 1992

URI : https://id.erudit.org/iderudit/050800ar

DOI : https://doi.org/10.7202/050800ar

Aller au sommaire du numéro

Éditeur(s)

Département des relations industrielles de l'Université Laval

ISSN

0034-379X (imprimé)

1703-8138 (numérique)

Découvrir la revue

Citer ce compte rendu

Hercus, T. (1992). Compte rendu de [Errol Black and Jim Silver, eds. Hard Bargains. The Manitoba Labour Movement Confronts the 1990's]. Relations industrielles / Industrial Relations, 47(3), 582-584.

https://doi.org/10.7202/050800ar

Tous droits réservés @ C Département des relations industrielles de l'Université Laval, 1992
Ce document est protégé par la loi sur le droit d'auteur. L’utilisation des services d'Érudit (y compris la reproduction) est assujettie à sa politique d'utilisation que vous pouvez consulter en ligne.

https://apropos.erudit.org/fr/usagers/politique-dutilisation/ 
Hard Bargains. The Manitoba Labour Movement Confronts the 1990's, édited by Errol Black and Jim Silver, Winnipeg, Manitoba, Manitoba Labour History Series, Manitoba Federation of Labour, 264 p., ISBN 0-4695258-1-8

The purpose of this book is to examine some of the challenges facing the Manitoba labour movement in the 1990's and to explore the ways in which the labour movement might best respond. There are a dozen essays in the volume which examine the major labour issues: public sector unionism, aboriginal people and the labour movement, labour legislation in Manitoba, affirmative action, health and safety, worker's compensation, plant closures, the unemployed help centre, anti-scab legislation and the Manitoba experience with final offer selection.

The editors set out their views of the tasks facing the labour movement which they consider crucial to success. First is the importance of mobilizing and politicizing the broad rank and file of the labour movement. A second task is the mounting of successful organizing drives aimed at building up labour's membership. A third task is the need to build coalitions with other grass roots movements. These tasks take union representatives far beyond negotiating and servicing collective agreements to a broadly based social unionism.

The editors start the book by reviewing Manitoba labour history in the postwar years. They provide the reader with an interesting account of the post-war years supporting their narrative with tables on union membership, trends in wage settlements, strikes and other indicators of industrial relations during this period. While the data is useful the narrative has a strong "labour spin" put on it.

In the following chapter the editors provide the results of interviews which they conducted with twenty-three trade union leaders in 1990 to determine how the labour movement in Manitoba sees the challenges of the 1990s and intends to respond to them. These interviews are supplemented by eight additional interviews conducted by C.B.C. reporter Ustun Renart in the summer of 1989.

The interviews are extremely candid, providing the reader with a clear insight into the problems confronting labour leaders in the 1990s: deskilling of carpentry for example, by the introduction of new less well-trained workers called installers; contractor's use of the merit shop system basing wages on "merit" combine to put the carpenters' union at risk of losing its role as sole supplier of skilled labour according to the trade union official interviewed.

The westward shift of kill plants closer to their source of raw materials and the eastward shift of processing plants to be closer to their large markets has resulted in major meat packing plant closures in Manitoba. This process is further threatened by the huge, low-cost American packing plants which are able to service this market as a result of the Free Trade Agreement. The result has been great pressure on Canadian meat packing wage levels and the loss of 2539 members to the UFCW Local 111 since 1976, as a result of fifteen plant closures. This has led to a merger of the packing house workers local with the Food and Commercial Workers Local with their stronger base of 4000 workers at Supervalu and Safeway. It is not clear to the union leaders how these membership losses can be made up in the future. 
For the Manitoba Government Employees Association, Manitoba's largest union $(29,000$ members), the threat is privatization of government services such as Manitoba Data Services soid to a private firm in 1990 and recently acquired by IBM Canada. The union fears as loss of jobs and a danger to the continuation of the collective agreement. The second threat is the government decision to decentralize 697 jobs from Winnipeg to other communities in Manitoba without consultation with the union.

The other interviews with labour leaders deal with broader issues: the linkage with the NDP party, labour legislation, mobilizing the membership, union organizing, public attitudes towards unions, coalition building, immigrant and aboriginal workers, women in the labour movement, and labour's vision for the future. While this chapter provides some interesting insights from the interviews with labour leaders it is interspersed with the authors' views on all topics discussed. It would have been more objective to have the interviews presented first followed by a separate section dealing with the authors' views of the interviews.

The conversational style of writing does hold the reader's interest as the authors' continue to make their case for a broadening of the labour agenda, returning to the social unionism of the thities and forties. They strongly believe that unless this happens the business union approach will lead to the type of decline experienced by U.S. unions.

The essays which follow examine that issue from the perspective of the potential coalition partners: aboriginal people, public sector unions, women's groups, health and safety, workers' compensation, and the unemployed. It is clear that the labour movement will have to learn to be a more effective partner if coalitions are to be built. The authors are quite candid on this issue of team building, consensus-building and action planning with other groups in society. While social unionism is a desirable goal for union growth and influence it will not be achieved without some major changes in labour's approach and a considerable increase in its understanding of the goals, aspirations and values of other groups who may be their coalition partners.

Several chapters are devoted to specific labour issues: labour legislation, anti-scab legislation, final offer selection and strategies for dealing with plant closures. These discussions provide useful insights and perspectives on critical issues facing the labour movement in the 1990s.

The editors of this volume have achieved their purpose set out in the introduction. They raise the awareness of the reader of the need to broaden the labour agenda to one of social unionism if the labour movement is to survive and grow in the 1990s. The purpose is clearly a valid one for those who value the labour movement in Manitoba.

A critical comment must be made regarding the book's title: Hard Bargains. This is the title of Bob White's autobiography. It is an appropriate title for White's book which does describe many hard bargains in his career. It is quite confusing and inappropriate to use the same title for a series of essays on social issues which are not "hard bargains" but rather issues of importance to labour leaders. 
The book is well written for the general reader by a number of authors within a general framework designed by the editors. The editors' chapters are especially well written; they present the main argument of the book with some passion. The book is recommended for the general reader interested in a labour perspective on social issues in the 1990s. It may also be useful as a set of readings for students in labour history or social issues courses at the university level.

Terry Hercus

The University of Manitoba

The Re-Education of the American Working Class, by Steven $\mathrm{H}$. London, Elvira R. Tarr and Joseph F. Wilson, eds., New York, Greenwood Press, 1990, 288 p., ISBN 0-313-26785-5, ISSN 0886-8239 (Lib. of Congress Catalog Card)

This is a rare and valuable book that primarily deals with educational programs for unionized workers in the United States. It is rare because of the paucity of academic attention that has been devoted to this subject in North America, and it is valuable because understanding the evolution of worker education, in all it varied forms, is intimately related to understanding the role of the labour movement in social and economic development. It also raises uncomfortable questions about the class character of post-secondary education.

The twenty-two papers that make up the book are previously unpublished works many of which were presented at a 1987 conference on Labor Education and Educating Labour which was held at Brooklyn College's Graduate Center for Worker Education, City University of New York. Some of the papers were solicited by the editors during the two years following the conference. The foreword to the book by Joseph S. Murphy, chancellor of the City University of New York, describes the need for the contributions in the book in terms of the waning influence of labour education after World War II, and the progressive disengagement of the universities from "nonelite causes and aspirations". $\mathrm{He}$ maintains that "[w]hat higher education ... created was a system of class differentiation that perfectly suited powerful economic interests: A middle class technically trained to fill corporate needs but largely unconcerned with the philosophic underpinnings of corporate society - and a working class economically powerless and intellectually unequipped to ask why". He, therefore, sees this volume as a stop towards reasserting the aspirations of that vast part of the population made up of workers and, at the same time, revalidating the social role of education in society.

There are a number of major themes that underlie many of the articles in this book. These include the effects of the tertiarization of employment on the demands for labour education, the implications of new technology for worker training, and the educational issues surrounding the growing importance of women in the labour force. Two important contributions deal with education and racism. There is also a recognition of the striking decline in United States union density rate in recent decades. Many of the contributors see new approaches to 